\section{To: (Receiving Organization)}

5. Proj./Prog./Dept./Div.:

Project $W-314$

\section{Originator Remarks:} impact on radiological sources, contamination control, or shielding". USQ not required per HNF-IP-0842, IV, 5.4, Rev. 12. Any temporary or permanent changes to

facilities and procedures covered by the RPP Authorization Basis that result from

the requirement of this document will have a USQ evaluation performed prior to field wark

11. Receiver Remarks:

11A. Design Baseline Document? $\square$ Yes $\square$ No
Distribution

For Release. "This modification will not increase collective dose since it has no

\author{
4. Related EDT No: \\ N/A \\ 7. Purchase Order No. \\ $\mathrm{N} / \mathrm{A}$ \\ 9. Equip./Component No: \\ $\mathrm{N} / \mathrm{A}$ \\ 10. System/Bldg./Facility: \\ $\mathrm{N} / \mathrm{A}$ \\ 12. Major Assm. Dwg. No.: \\ $\mathrm{N} / \mathrm{A}$ \\ 13. Permit/Permit Application No. \\ $\mathrm{N} / \mathrm{A}$
}

14. Required Response Date:

$\mathrm{N} / \mathrm{A}$

\begin{tabular}{|c|c|}
\hline $\begin{array}{l}(A) \\
\text { Item } \\
\text { No. }\end{array}$ & $\theta r_{4-12 .}^{(B)}$ Dogument/Drawing No. \\
\hline 1 & $\not X / Z-6160$ \\
\hline & RPP \\
\hline & \\
\hline & \\
\hline & \\
\hline & \\
\hline & \\
\hline
\end{tabular}

DATA TRANSMITTED

16.

\begin{tabular}{c|c|c}
$\begin{array}{c}\text { (C) Sheet } \\
\text { No. }\end{array}$ & (D) Rev. \\
No. & (E) Title or Description of Data Transmitted
\end{tabular}

(F)

(G)

\begin{tabular}{|c|c|c|}
\hline$(H)$ & $(I)$ \\
\hline & $\begin{array}{c}\text { Origi- } \\
\text { nator } \\
\text { Dispo- } \\
\text { stion }\end{array}$ & $\begin{array}{c}\text { Receiv- } \\
\text { er } \\
\text { Dispo- } \\
\text { sition }\end{array}$ \\
\hline & & \\
\hline & & \\
\hline
\end{tabular}

KEY

\begin{tabular}{|l|}
\hline Risk Management Plan for \\
\hline Tank Farm Restoration and \\
\hline Safe Operations \\
\hline
\end{tabular}

Approval Reason nator 1 mittal

ESQ

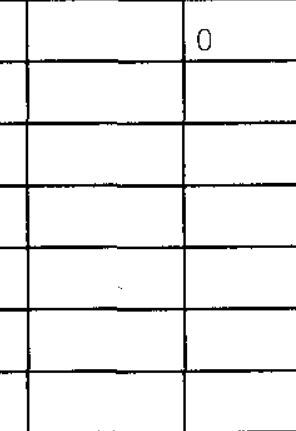

Approval Designator $(F)$

Reason for Transmittal (G)

E, S, Q, D OR N/A Sec. 12.7)

1. Approval
2. Release
3. Information

4. Review

5. Post-Review

6. Dist. (Receipt Acknow. Required)

\begin{tabular}{|ll}
\hline \multicolumn{2}{|c}{ Disposition (H) \& (I) } \\
$\begin{array}{ll}\text { 1. Approved } & \text { 4. Reviewed no/comment } \\
\text { 2. Approved w/comment } & \text { 5. Reviewed w/comment } \\
\text { 3. Disapproved w/comment } & \text { 6. Receipt acknowledged }\end{array}$ \\
\hline
\end{tabular}

SIGNATURE/DISTRIBUTION

17

(See Approval Designator for required signatures)

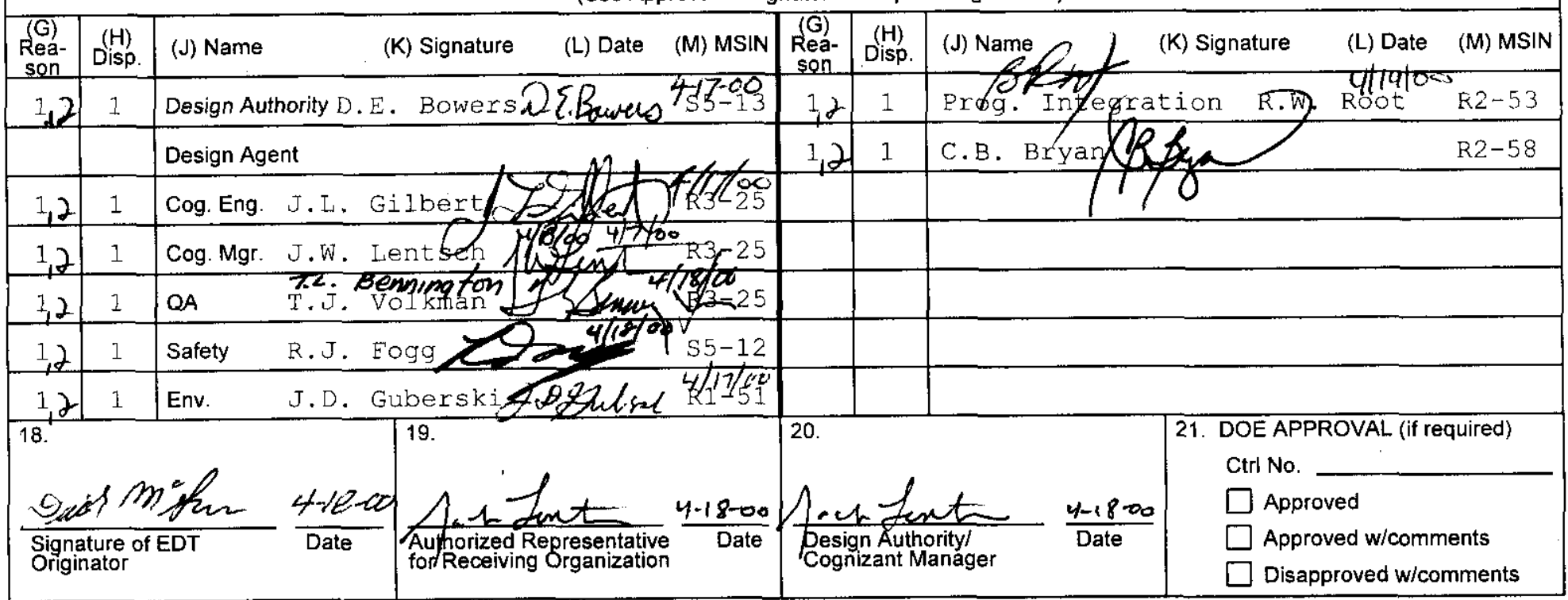




\title{
Risk Management Plan for Tank Farm Restoration and Safe Operations, Project W-314
}

\author{
D. L. McGrew \\ Numatec Hanford Corporation \\ Richland, WA 99352 \\ U.S. Department of Energy Contract DE-AC06-96RL13200 \\ EDT/ECN: $628194 \quad$ UC: \\ Org Code: 7C300 Charge Code: 109749 \\ B\&R Code: Total Pages: 9
}

Key Words: Risk Management Plan, Tank Farm Restoration and Safe operations, Office of River Protection, Project $W-314$.

\begin{abstract}
The Risk Management Plan for Project $W-314$ describes the systems, processes and procedures for implementation of applicable risk management practices described in HNF-0842, Volurne IV, Section 2.6, "Risk Management". This plan is tailored specifically for use by Project $W-314$.
\end{abstract}

TRADEMARK DISCLAIMER. Reference herein to any specific commercial product, process, or service by trade name, trademark, manufacturer, or otherwise, does not necessarily constitute or imply its endorsement, recommendation, or favoring by the United States Government or any agency thereof or its contractors or subcontractors.

Printed in the United States of America. To obtain copies of this document, contact: Document Control Services, P.O. Box 950, Mailstop H6-08, Richland WA 99352, Phone (509) 372-2420; Fax (509) 376-4989.
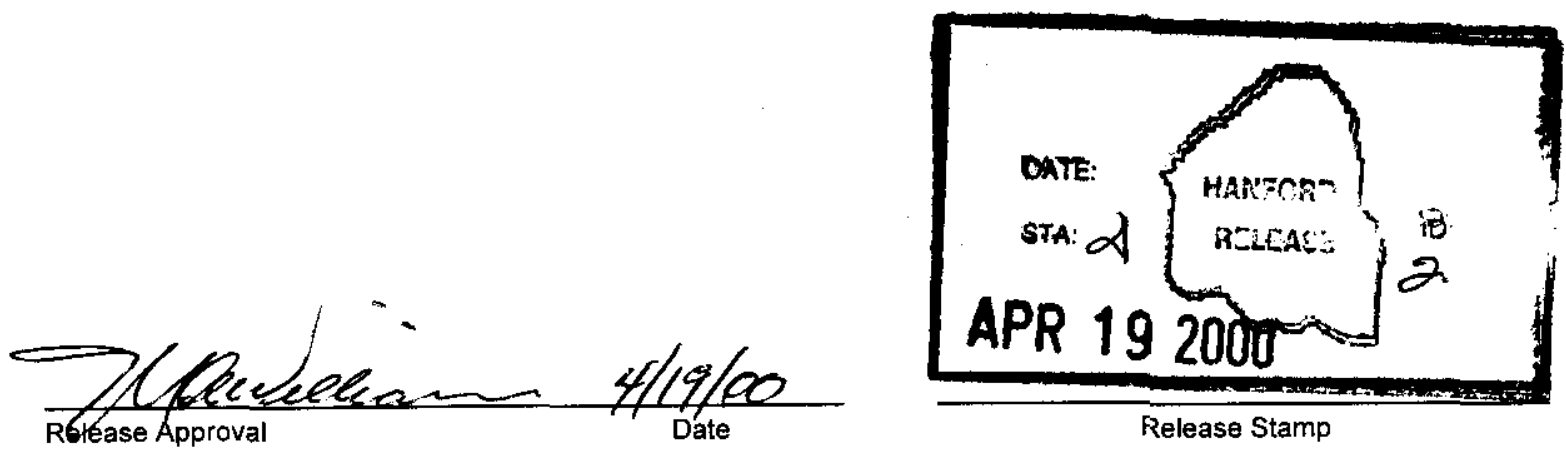

\section{Approved For Public Release}


RPP-6160, Rev. 0

\title{
RISK MANAGEMENT PLAN
}

For

TANK FARMS RESTORATION

AND SAFE OPERATIONS

PROJECT W-314

\author{
Prepared for the \\ U.S. Department of Energy \\ Office of River Protection \\ by \\ CH2M HILL Hanford Group, Inc. \\ Revised \\ April 2000
}




\section{TABLE OF CONTENTS}

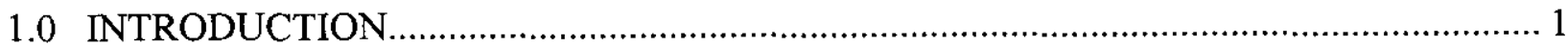

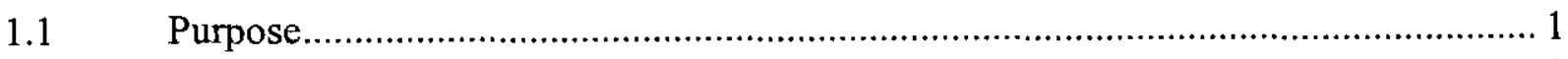

$1.2 \quad$ Scope

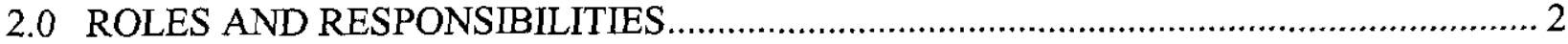

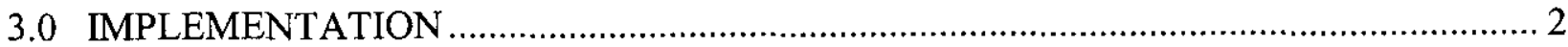

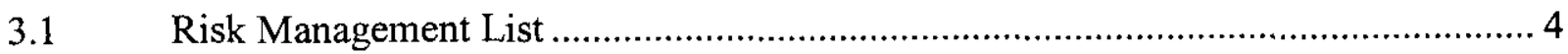

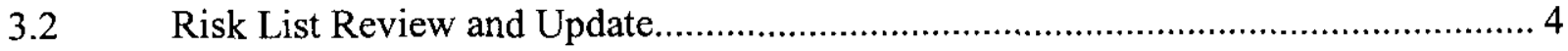

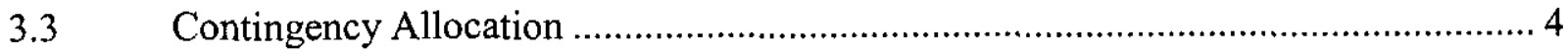

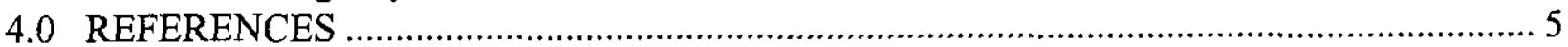

\section{LIST OF TABLES}

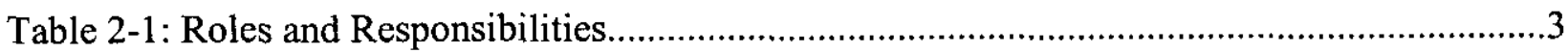




\section{ACRONYMS and ABBREVIATIONS}

CHG CH2M HILL Hanford Group, Inc.

ORP U.S. Department of Energy, Office of River Protection Project Execution Plan

RML Risk Management List

RMP Risk Management Plan

RPP River Protection Projects

SEMP Systems Engineering Management Plan

SME Subject Matter Expert

TBR

Technical Basis Review 
RPP-6160, Rev. 0

\subsection{INTRODUCTION}

This document provides a project-level Risk Management Plan (RMP), which is in accordance with the requirements of River Protection Project's (RPP) procedure HNF-IP-0842, Volume IV, Section 2.6, Risk Management.

Project W-314, Tank Farm Restoration and Safe Operations (TFRSO), is a Fiscal Year (FY) 1997 new start line item project within the RPP strategic system. Project W-314 provides upgrades for the existing tank farms waste transfer, instrumentation, ventilation, and electrical support systems, and supports the upgrades necessary for the waste feed delivery to the Privatization Contractor for vitrification and waste disposal.

Risk Management for the Project involves creation of a work environment where risks are identified, understood, and managed. The primary tool for communicating Project risks is the Project W-314 Risk Management List (RML), which identifies risk events and mitigation actions. The mitigating action and risks may be further defined and placed on a separate risk/action list for "real-time" management as risks and mitigation actions evolve.

Project risks affecting the program's Technical Basis Review (TBRs) or critical program missions will follow, as applicable, the steps presented in the RPP procedure, Risk Management, and are included in Section 8.0, Risk Events - Scope, Schedule and/or Cost, of the applicable TBRs.

Risk management is an integral part of the project management function, which is to allocate resources to achieve certain goals with minimum risk. The primary objective of project risk management is to identify risks related to the successful completion of the project, the mitigation strategy to be employed, and management activities and responsibilities. The mitigation strategy allows the project to assign appropriate project cost and schedule contingencies for the identified risks.

The risk analysis process described in this document applies to both Phase 1 and Phase 2 of the Project

\subsection{Purpose}

The purpose of this RMP is to define the strategy to be used by Project W-314 to implement the requirements of RPP's procedure Risk Management.

\subsection{Scope}

Project risk management is applied to project planning that reflects prioritization of the tank farm upgrades defined by ORP's RPP organization. The project planning necessary to execute this prioritization has been established using a "phased upgrades" approach. 


\subsection{ROLES AND RESPONSIBILITIES}

This section includes Table 2-1which describes the anticipated roles and responsibilities of the various managers in implementing the RMP. It also describes the specific administrative actions required to manage project risks and maintain risk management tools for tracking risk management activities. These are generic positions as described in the RPP procedure, Risk Management. However, the Project W-314 equivalent is noted for each. The W-314 RML assigns individual responsibilities.

\subsection{IMPLEMENTATION}

The steps shown below present a typical summary of how a Risk Management List (RML) can be generated, maintained, and utilized, as applicable, by Project W-314. The steps shown are not necessarily performed in sequence but rather can be performed as dictated by the information available at the time

\section{Risk Assessment}

$1 \quad$ Assess Risk Elements

2 Identify Risk Events

\section{Risk Analysis}

$\begin{array}{ll}3 & \text { Determine Risk Impacts } \\ 4 & \text { Develop Handling Actions } \\ 5 & \text { Determine Residual Risk Impacts } \\ 6 & \text { Analyze Risk Events } \\ 7 & \text { Prepare Risk Lists }\end{array}$

\section{Risk Handling}

$\begin{array}{ll}8 & \text { Implement Handling Actions } \\ 9 & \text { Monitor Handling Actions } \\ 10 & \text { Close Handling Actions }\end{array}$


RPP-6160, Rev. 0

Table 2-1: Roles and Responsibilities

\begin{tabular}{|c|c|}
\hline W-314 Position & Position Description and Administrative Actions \\
\hline $\begin{array}{l}\text { DOE-ORP Point- } \\
\text { of-Contact }\end{array}$ & $\begin{array}{l}\text { The DOE-ORP W- } 314 \text { Point-of-Contact evaluates program risks, establishes customer } \\
\text { requirements and priorities, and assists in the mitigation of risks for institutional jssues } \\
\text { (scope, schedule or budget changes from federal budgets, Environmental Impact Statements, } \\
\text { Tri-Party Agreements etc.). }\end{array}$ \\
\hline $\begin{array}{l}\text { W-314 Project } \\
\text { Manager }\end{array}$ & $\begin{array}{l}\text { Initial duty of the W-314 Project Manager is to implement this RMP and coordinate activities } \\
\text { with the ORP Point-of-Contact, when necessary. The Project Manager is responsible for } \\
\text { review of the RML with the project team members. The Project Manager is also responsible } \\
\text { for assigning the risk owners, risk handlers, and risk analysts for critical risks. In many } \\
\text { instances, the Project Manager acts as risk owner for risks associated with his/her project. }\end{array}$ \\
\hline Risk Owner & $\begin{array}{l}\text { The Risk Owner is responsible for overseeing the risk item and tracking the Action Items to } \\
\text { completion, ensuring personnel complete actions assigned, providing support and } \\
\text { coordination where needed, keeping the project manager informed of the status of the risk } \\
\text { handling efforts, and closing out of the Risk Action Plan. The Risk Owner is responsible for } \\
\text { the success of a subsection of the project and controls the resources required to effect that } \\
\text { outcome. }\end{array}$ \\
\hline Risk Handler & $\begin{array}{l}\text { The Risk Handler is responsible for ensuring that assigned risk handling actions are } \\
\text { completed within the expected due date, keeping the Risk Owner informed on a routine basis } \\
\text { of the status of the assigned action items, and elevating problems to management for quick } \\
\text { resolution when the need arises. Although individual tasks can be delegated, the } \\
\text { responsibility is not delegable. }\end{array}$ \\
\hline Systems Engineer & $\begin{array}{l}\text { The Systems Engineer is primarily responsible for maintaining and disseminating the RMP } \\
\text { and RML. An additional responsibility is maintenance of the RML Database and generation } \\
\text { of needed reports. }\end{array}$ \\
\hline $\begin{array}{l}\text { Technical } \\
\text { Contributors }\end{array}$ & $\begin{array}{l}\text { These engineers and technicians are responsible for working with the Project Manager and } \\
\text { Risk Owners/Handlers to identify and mitigate risks associated with their tasks. Identified } \\
\text { risks are added to the RML. The Technical Contributors are also responsible for providing } \\
\text { activity status to the Risk Owners. Within W-314, the engineers in each of the four } \\
\text { disciplines (ventilation, waste transfer, electrical, instrumentation) fulfill these positions. }\end{array}$ \\
\hline Risk Analyst & $\begin{array}{l}\text { The Risk Analyst assists in the identification of risk data and the development of risk } \\
\text { management data products (e.g., project risk model, completed Risk Handling Action Plan } \\
\text { Worksheets, Risk Analysis Data Sheets, Project Risk List, etc.) for each program or project. }\end{array}$ \\
\hline
\end{tabular}


The primary risk assessment and analysis technique to be employed on Project W-314 is expert interviews. This technique is applicable for use in gathering the information needed in Steps 1, 2, 3, 4, and 5. Appropriate Subject Matter Experts (SMEs) are questioned about the potential risks, and their consequences, in their area of expertise, as related to W-314.

Descriptions and the implementation process for the 10 steps above are found in the RPP procedure, Risk Management, and used as applicable.

\subsection{Risk Management List}

Once the risk events are identified and risk handling actions defined, as applicable, the events are added to the W-314 RML. The W-314 RML is a summary of the W-314 risk events with the status of related risk management (mitigation/control) efforts.

The W-314 RML is a part of a larger hierarchy of risks which are identified in the program's TBRs. Risks considered programmatic in nature will be considered for elevation to a higher management level. In addition, broader programmatic risks may also be identified and added onto each successively higher level list. Such addition of risks to the higher level risk lists shall be made at the discretion of the managers responsible for those lists.

\subsection{Risk List Review and Update}

The W-314 RML is a "living document," which will be updated quarterly, or earlier as needed. The update is conducted to add or remove items from the list, and to ensure that the identified actions are accomplishing their intended purpose. New risks can be added to the RML at any time deemed necessary.

\subsection{Contingency Allocation}

Project W-314 included contingency allocations for Phase 1, and 2, as addressed in HNF-3781 and HNF-5109 rebaseline reports. Contingency allocations were based on quantification of the risks identified, cost of mitigation, and potential residual costs after mitigation. Similarly, Project risk information is also derived and submitted with the TBRs during Program's yearly planning effort. 
RPP-6160, Rev. 0

\subsection{REFERENCES}

HNF-3939, Revision 0, Risk Management List and Supporting Information for Project $W-314$ HNF-3781, Phase 1 Rebaseline Report for Tank Farm Restoration and Safe Operations

HNF-5109, Phase 2 Rebaseline Report for Tank Farm Restoration and Safe Operations

HNF-IP-0842, Volume IV, Section 2.6, Risk Management

HNF-SD-WM-SEMP-002, River Protection Projects Systems Engineering Management Plan 


\section{DISTRIBUTION SHEET}

To

Distribution

Project Title/Work Order

W-314, Tank Farm Restoration and Safe Operations

Name

J.B. Bailey

D.E. Bowers

T.J. Volkman

T.E. Nugent

J.I. Gilbert

C.B. Bryan

R.W. Root

D. L. McGrew

B.L. Syverson

J.W. Lentsch

R. J. Fogg

M. F. Erhart

K.B. Ferlan

R.R. Bevins

D.E. Legare

O.D. Nelson

J.D. Guberski

C.A. Burke

N.K. Butler

Project Eiles

Project Library
From

TER\&SO

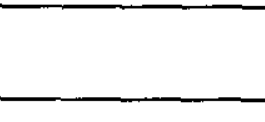

Page 1 of 1
Date
EDT No. 628194
ECN No.

\begin{tabular}{|c|c|c|c|c|}
\hline $\mathrm{MSI}$ & $\begin{array}{c}\text { Text } \\
\text { With All } \\
\text { Attach. }\end{array}$ & Text Only & $\begin{array}{l}\text { Attach./ } \\
\text { Appendix } \\
\text { Only }\end{array}$ & $\begin{array}{c}\text { EDT/ECN } \\
\text { Only }\end{array}$ \\
\hline
\end{tabular}

